\title{
Corrigendum
}

\section{Improved computer-assisted analysis of the global lymphatic network in human cervical tissues}

Cédric Balsat, Nicolas Signolle, Frédéric Goffin, Katty Delbecque, Benoit Plancoulaine, Philippe Sauthier, Vanessa Samouëlian, Aude Béliard, Carine Munaut, Jean-Michel Foidart, Silvia Blacher, Agnès Noël and Frédéric Kridelka

Modern Pathology (2017) 30, 313; doi:10.1038/modpathol.2016.196

Correction to: Modern Pathology (2014) 27, 887-898; published online 06 December 2013; doi:10.1038/ modpathol.2013.195

In this paper, Figure 5 is incorrect. The correct version of Figure 5 is provided below. The authors regret the error.
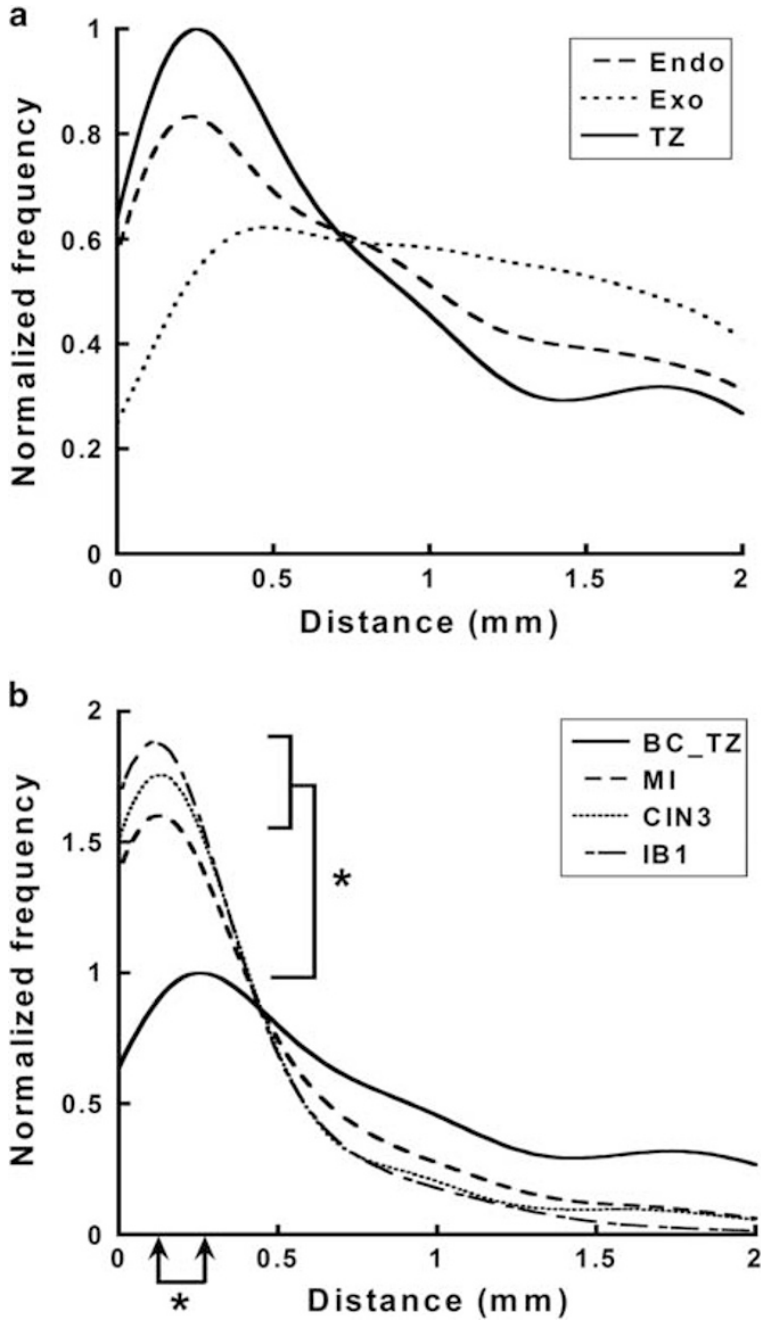

Figure 5 